\title{
KAJIAN PENANGGULANGAN GENANGAN YANG TERINTEGRASI DI KAWASAN PILANG, PROBOLINGGO
}

\author{
Rahma Rismasari ${ }^{1}$, Donny Harisuseno ${ }^{2}$, dan Andre Primantyo Hendrawan ${ }^{2}$ \\ ${ }^{1}$ Staf Dinas Pekerjaan Umum \& Penataan Ruang Kabupaten Probolinggo \\ ${ }^{2}$ Dosen Jurusan Teknik Pengairan, Fakultas Teknik, Universitas Brawijaya, Malang \\ Email : ${ }^{1}$ rahmarismasari@gmail.com, ${ }^{2}$ donnyhari@yahoo.com, ${ }^{2}$ aphendra05@yahoo.com
}

\begin{abstract}
ABSTRAK: Permasalahan genangan yang terjadi di daerah perkotaan mengekspresikan tidak terakomodirnya dengan baik kapasitas saluran drainase dan ketersediaan daerah resapan. Begitupun yang terjadi di Kawasan Pilang Probolinggo. Genangan menjadi permasalahan tahunan saat musim hujan tiba. Penelitian ini mengkaji penanggulangan genangan secara terintegrasi antara sistem baru yang diusulkan berupa sumur tampungan, dan kolam detensi dengan sistem drainase eksisting. Curah hujan rancangan dihitung dengan metode Gumbel dan Metode Log Person Tipe III untuk kemudian dibandingkan hasilnya, dan dipilih yang memenuhi persyaratan. Karena merupakan integrasi dari kerja 2 (dua) sistem drainase, sehingga perlu dianalisis potensi dalam mereduksi genangan dan potensi dalam menambah waktu tiba banjir. Dari hasil analisis diperoleh bahwa kejadian genangan historis mendekati perhitungan intensitas hujan kala ulang 2 tahun, sehingga sistem yang diusulkan didesain atas dasar debit rancangan kala ulang 5 tahun. Curah hujan rancangan diperoleh dengan metode Log Person Tipe III sebesar $125.304 \mathrm{~mm}$. Dari hasil evaluasi kapasitas saluran terhadap debit rancangan, terdapat 12 saluran drainase eksisting yang kapasitasnya tidak memadai dalam menerima beban debit rancangan. Upaya penanggulangan secara terintegrasi dapat mereduksi genangan hingga $100 \%$, dan dapat menunda waktu tiba banjirnya sebesar $83 \%$ pada 12 saluran yang diidentifikasikan terjadi genangan tersebut.
\end{abstract}

Kata kunci: genangan, waktu konsentrasi, sistem drainase terintegrasi, reduksi banjir, sumur tampungan

\begin{abstract}
The flood problem that occurs in urban areas mostly related on a lack of drainage channel capacity and the change of land use and catchment areas. In the area of Pilang Probolinggo, the inundation becomes an annual problem especially at rainy seasons. This study proposes an integrated flood management as a combination of storage wells, and detention pools with existing drainage systems. The design rainfall is calculated by Gumbel method and Log Person Type III Method, then by compared their results the eligible design rainfall can be selected. As an integration of two drainage systems, the potential to reduce inundation and to increase the flood arrival time of this system should be analyzed properly. From the analysis results it is observed that the occurrence of historical inundation was approached the calculation of rain intensity of 2 years return period; so the proposed system is designed based on the discharge design of 5 years return period. The design rainfall obtained by Log Person Type III method is $125.304 \mathrm{~mm}$. Based on flood discharge design, it can be evaluated that 12 existing drainage channels had inadequate capacity. As a final result, the integrated flood management proposed by this study can reduce the inundation up to $100 \%$, and can delay the flooding time of $83 \%$ in the 12 channels within the area of inundation.
\end{abstract}

Keywords: inundation, time of concentration, integrated drainage system, flood reduce, storage well

Saat musim penghujan tiba genangan menjadi salah satu permasalahan yang di-hadapi hampir setiap wilayah perkotaan di Indonesia, tak terkecuali Kota Probolinggo. Beragam 
permasalahan drainase membutuhkan solusi penanganan untuk mengurangi kerawanan terhadap akibat yang ditimbulkan. Terjadinya genangan berkaitan erat dengan kapasitas saluran drainase dan tersedianya daerah resapan, apabila tidak terakomodasi dengan baik pasti akan menimbulkan permasalahan.Terdapat dua kemungkinan penyebab terjadinya genangan karena hujan di suatu kawasan. Pertama, intensitas hujan lebih besar daripada perhitungan dalam perencanaan saluran drainase. Kedua, intensitas hujan sesuai dengan perencanaan akan tetapi limpasan air hujan tidak mampu ditampung oleh saluran drainase yang ada (Munadhir 1995 dalam Susilowati, 2006).

Lokasi studi (kawasan Pilang) merupakan daerah langganan genangan saat musim penghujan tiba. Beberapa faktor yang menyebabkan terjadinya genangan antara lain kapasitas saluran drainase eksisting yang tidak memadai, semakin berkurangnya daerah re-sapan sedangkan jaringan drainase yang ada relatif tetap, serta terbatasnya daerah yang memadai untuk dilakukan perluasan kapasitas saluran drainase eksisting.

Hasil observasi pengamatan langsung di lapangan dan berdasarkan informasi dari Instansi terkait yaitu Dinas PU dan Penataan Ruang Kota Probolinggo, kejadian genangan historis di daerah studi untuk setiap kejadian hujan mencapai ketinggian $40 \mathrm{~cm}$ hingga 50 $\mathrm{cm}$, dengan durasi genangan 2 (dua) jam hingga 3 (tiga) jam, sedangkan menurut Permen PU No. 14 tahun 2010 tentang Standart Pelayanan Minimal Bidang Pekerjaan Umum dan Penataan Ruang bahwa standart pelayanan minimal untuk saluran drainase adalah harus tersedianya sistem jaringan drainase skala kawasan dan skala kota sehingga tidak terjadi genangan (lebih dari 30 $\mathrm{cm}$, selama 2 (dua) jam dan tidak lebih dari 2 (dua) kali dalam setahun).

Dari permasalahan yang ada, menjadikan kawasan Pilang Kota Probolinggo layak untuk dijadikan fokus kajian dalam upaya menanggulangi genangan yang terjadi.

Penelitian ini dilakukan untuk mengevaluasi kapasitas saluran drainase eksisting, mengetahui bentuk penanganan genangan yang terintegrasi dengan sistem drainase eksisting yang bisa diterapkan di lokasi studi, serta untuk mengetahui bagaimana potensi sistem penanggulangan yang diusulkan dalam me- reduksi genangan dan dalam menambah waktu tiba banjir.

\section{METODE PENELITIAN \\ Lokasi Studi}

Studi mengenai Kajian Penanggulangan Genangan yang Terintegrasi ini difokuskan pada Kawasan Pilang Kota Probolinggo. Kawasan Pilang masuk dalam wilayah administrasi Kelurahan Tisnonegaran dan Kelurahan Kanigaran.

\section{Pengumpulan Data}

Dalam penyelesaian studi ini diperlukan data pendukung untuk menganalisis daerah studi. Data-data yang diperlukan antara lain berupa data primer dan data sekunder.

Data primer diperoleh dengan melakukan observasi pengamatan dan pengukuran langsung di lapangan. Data primer terdiri dari data saluran drainase eksisting, data arah aliran, dan data koefisien permeabilitas tanah $(\mathrm{K})$.

Sedangkan data sekunder diperoleh dari Instansi terkait (Dinas PUPR Kota Probolinggo, Bappeda Kota Probolinggo) yang telah terlebih dahulu melakukan pengukuran, terdiri dari data curah hujan pada 4 (empat) stasiun penakar hujan di Kota Probolinggo selama 27 (dua puluh tujuh) tahun, peta topografi, peta tata guna lahan, data tinggi muka air tanah, data koordinat letak stasiun penakar hujan, dan data teknis saluran drainase eksisting.

\section{Pengolahan Data}

\section{- Analisis Hidrologi}

a) Melakukan uji kualitas data terhadap data curah hujan di 4 (empat) stasiun penakar hujan di Kota Probolinggo antara lain uji konsistensi data, uji ke-tidakadaan trend, uji stasioner atau uji homogenitas data hujan), uji persistensi, dan uji outliers. Serangkaian uji kualitas data tersebut dilakukan untuk me-mastikan bahwa data yang akan digunakan dalam analisis hidrologi adalah data yang berkualitas, karena kualitas data sangat mempengaruhi hasil analisisnya;

b) Menghitung curah hujan daerah yang berasal dari data curah hujan harian maksimum dengan metode Poligon Thiessen;

c) Menghitung curah hujan rancangan menggunakan 2 (dua) metode distribusi frekuensi yaitu metode Log Person Tipe III dan metode Gumbel, dengan pertimbangan 
bahwa kedua metode tersebut lebih dapat digunakan untuk semua jenis sebaran data;

d) Melakukan uji kesesuaian distribusi frekuensi terhadap hasil analisis curah hujan rancangan secara vertikal dengan uji Chi Square dan secara horizontal dengan uji Smirnov-Kolmogorov;

e) Memilih hasil curah hujan rancangan dari 2 (dua) metode distribusi frekuensi yang memenuhi persyaratan.

- Analisis Debit Rancangan

a) Menghitung volume genangan yang terjadi. Besarnya volume genangan his-toris digunakan sebagai acuan penentuan periode kala ulang yang akan digunakan dalam perencanaan.

b) Menghitung intensitas hujan dengan menggunakan rumus Mononobe, karena rumus ini dapat digunakan untuk menghitung waktu (t) sembarang (Soemarto, 1999:15);

c) Menghitung luas daerah pengaliran pada setiap saluran untuk mengetahui daerah mana saja yang mempengaruhi penga-liran pada tiap-tiap saluran berdasarkan observasi pengamatan langsung arah aliran di lapangan, pembacaan peta topografi daerah studi, hasil wawancara atau masukan dari penduduk sekitar, dan informasi dari Instansi terkait (Dinas PUPR Kota Probolinggo);

d) Menghitung besarnya luasan peng-gunaan lahan pada setiap saluran berdasarkan peta tata guna lahan yang akan digunakan untuk menghitung koefisien pengaliran;

e) Menghitung debit air hujan $\left(\mathrm{Q}_{\mathrm{AH}}\right)$ dengan menggunakan metode Rasional, karena metode rasional dapat digunakan untuk perencanaan saluran drainase pada daerah pengairan yang relatif sempit (Sosrodarsono, 1978:144);

f) Menghitung debit limbah domestik $\left(Q_{A K}\right)$.

g) Menghitung debit rancangan total $\left(Q_{R}\right)$ yaitu jumlah dari debit air hujan dan debit limbah domestik. $\mathrm{Q}_{\mathrm{R}}=\mathrm{Q}_{\mathrm{AH}}+\mathrm{Q}_{\mathrm{AK}}$

- Analisis Evaluasi Kapasitas Saluran Drainase

a) Menghitung kapasitas saluran drainase eksisting berdasarkan data-data teknis saluran drainase eksisting dengan pendekatan rumus Manning; b) Mengevaluasi kemampuan kapasitas saluran drainase eksisting terhadap debit rancangan.

\section{- Analisis Penanggulangan Genangan}

a) Mengetahui karakteristik daerah studi, dengan mengambil sampel tanah pada daerah studi untuk dilakukan serang-kaian pengujian tanah, sehingga dapat diketahui nilai permeabilitas tanahnya;

b) Menganalisis perencanaan sumur tampungan;

c) Menganalisis perencanaan kolam de-tensi;

- Analisis potensi integrasi antara sistem penanggulangan genangan yang diusulkan dengan sistem drainase eksisting dalam mereduksi genangan yang terjadi dan dalam menambah waktu tiba banjirnya.

a) Menghitung prosentase reduksi debit genangan terhadap debit rancangan setelah penanganan;

b) Menghitung prosentase penambahan waktu tiba banjir, dengan membanding-kan lama waktu tiba banjir sebelum penanganan dan setelah penanganan.

\section{Debit Rancangan}

Metode Rasional merupakan rumus empirik sederhana yang masih banyak digunakan saat ini untuk menghitung debit puncak banjir $\left(Q_{R}\right)$ (Rahmani, 2016). Menurut Rahmani (2016) dalam perhitungannya, metode rasional telah memasukkan karakteristik hidrologi dan proses aliran yaitu: (1) intensitas hujan, (2) durasi hujan, (3) luas DAS, (4) kehilangan air akibat evaporasi, intersepsi, infiltrasi, dan (5) konsentrasi aliran.

Sedangkan menurut Suripin (2004) dalam Solikin (2017) metode untuk memperkirakan laju aliran permukaan puncak yang umum digunakan adalah metode Rasional. Metode ini sangat sederhana dan penggunannya terbatas pada DAS dengan ukuran kecil, yaitu kurang dari $300 \mathrm{Ha}$.

$\mathrm{Q}=0.002788 \times \mathrm{C} \times \mathrm{I} \times \mathrm{A}$ dengan $\mathrm{Q}$ adalah debit puncak ( $\mathrm{m}^{3} /$ detik); $\mathrm{C}$ adalah koefisien aliran permukaan, I adalah intensitas hujan (mm/jam) dan A adalah luas daerah tangkapan air (Ha).

\section{Waktu Konsentrasi}

Salah satu data yang diperlukan untuk menghitung debit puncak banjir metode 
rasional adalah waktu konsentrasi (time of concentration) sebesar tc, yaitu waktu yang diperlukan curah hujan mengalir dari titik paling hulu suatu DPS hingga aliran itu sampai di titik pengeluaran (outlet) DPS itu (Soewarno, 2000:231). Salah satu metode untuk memperkirakan waktu konsentrasi adalah rumus yang dikembangkan oleh Kirpich (Suripin, 2004:82):

$\mathrm{tc}=\left(\frac{0.87 \times \mathrm{L}^{2}}{1000 \times \mathrm{S}}\right)^{0.385}$

dengan tc adalah waktu konsentrasi (jam); L adalah panjang saluran utama dari hulu sampai penguras $(\mathrm{km})$; dan $\mathrm{S}$ adalah kemiringan ratarata saluran utama $(\mathrm{m} / \mathrm{m})$.

\section{Evaluasi Kapasitas Saluran Eksisting}

Evaluasi kapasitas saluran dimaksudkan untuk mengkaji kemampuan saluran drainase eksisting terhadap debit banjir rancangan.

Pada dasarnya debit yang mampu dilewatkan oleh suatu saluran drainase dapat dilakukan pendekatan menggunakan Rumus Manning (Suripin, 2004:144) yaitu:

$\mathrm{Q}_{\mathrm{S}}=\mathrm{Vsal} \times \mathrm{A}$

dimana:

$\mathrm{V}=\frac{1}{\mathrm{n}} \times \mathrm{R}^{\frac{2}{3}} \times \mathrm{I}^{\frac{1}{2}}$

dengan $\mathrm{Q}_{\mathrm{s}}$ adalah kapasitas saluran ( $\mathrm{m}^{3} /$ detik); Vsal adalah kecepatan aliran di saluran (m/detik), A adalah luas penampang basah saluran $\left(\mathrm{m}^{2}\right), \mathrm{R}$ adalah jari-jari hidraulis $(\mathrm{m})$; dan I adalah kemiringan dasar saluran.

Apabila $Q_{S}>Q_{R}$ maka saluran aman, sebaliknya jika $\mathrm{Q}_{\mathrm{S}}<\mathrm{Q}_{\mathrm{R}}$ maka pada saluran terjadi limpasan, sehingga diperlukan alternatif penanganan terhadap kondisi tersebut.

\section{Koefisien Permeabilitas}

Angka koefisien permeabilias tanah akan mempengaruhi kecepatan peresapan. Tanah yang mempunyai angka koefisien permeabilitas tinggi akan mempunyai kapasitas peresapan yang besar. Nilai koefisien permeabilitas tanah dapat dilihat pada Tabel 1 .

Tabel 1 Rentang Nilai Koefisien Permeabilitas

\begin{tabular}{c|l|c}
\hline \multicolumn{1}{c|}{ Peneliti } & \multicolumn{1}{|c}{ Karakteristik } & \multicolumn{1}{c}{$\begin{array}{c}\text { Nilai K } \\
(\mathrm{cm} / \text { detik })\end{array}$} \\
\hline Bowles (1991) & Lanau Kelempungan & $10^{-4}-10^{-9}$ \\
\hline \multirow{4}{*}{ Das (1995 } & Kerikil sedang sampai kasar & $>10^{-1}$ \\
\cline { 2 - 3 } & Pasir halus sampai kasar & $10^{-1}-10^{-3}$ \\
\cline { 2 - 3 } & Pasir halus, pasir berlanau & $10^{-3}-10^{-5}$ \\
\cline { 2 - 3 } & Lanau, Lanau berlempung, lempung berlanau & $10^{-4}-10^{-6}$ \\
\cline { 2 - 3 } & Lempung Gemuk & $<10^{-7}$ \\
\hline
\end{tabular}

Sumber: Hendra Irawan, Soewignjo, Syawal Satibi.

HASIL DAN PEMBAHASAN

\section{Batas Daerah Tangkapan Air (DTA)}

Melalui analisis peta topografi dan berdasarkan observasi pengamatan arah aliran di lapangan didapatkan batas Daerah Tangkapan Air (DTA) pada lokasi studi. DTA pada daerah studi memiliki luas areal $24.724 \mathrm{Ha}$ sebagaimana disajikan pada Gambar 1.

\section{Uji Kualitas Data Hujan}

Dalam hal mendapatkan hasil analisis yang baik, diperlukan data yang berkualitas. Untuk mengetahui kualitas dari data hidrologi yang tersedia diperlukan serangkaian pengujian terhadap data tersebut. Hasil uji konsistensi data hujan yang tersedia dari 4 (empat) stasiun penakar hujan di Kota
Probolinggo diperoleh bahwa data hujan dalam batas konsisten, dari hasil uji ketidakadaan trend menunjukkan bahwa data bersifat independent, hasil uji stasioner menunjukkan bahwa nilai varian dan nilai rata-rata dari data hujan bersifat stabil, hasil uji persistensi diperoleh bahwa data hujan bersifat acak, sedangkan untuk uji outliers terdapat satu data pada Stasiun Probolinggo (data tahun 2009) merupakan data outliers, oleh karena ketersediaan data cukup panjang yaitu selama 27 (dua puluh tujuh) tahun, maka data tersebut dihilangkan. Dengan menghilangkan data diharapkan dapat memberikan hasil analisis hidrologi yang baik karena data akan semakin mendekati nilai rata-ratanya. 
Dari hasil serangkaian pengujian terhadap kualitas data yang dilakukan menunjukkan bahwa data hidrologi yang tersedia cukup handal untuk dilakukan analisis hidrologi selanjutnya.

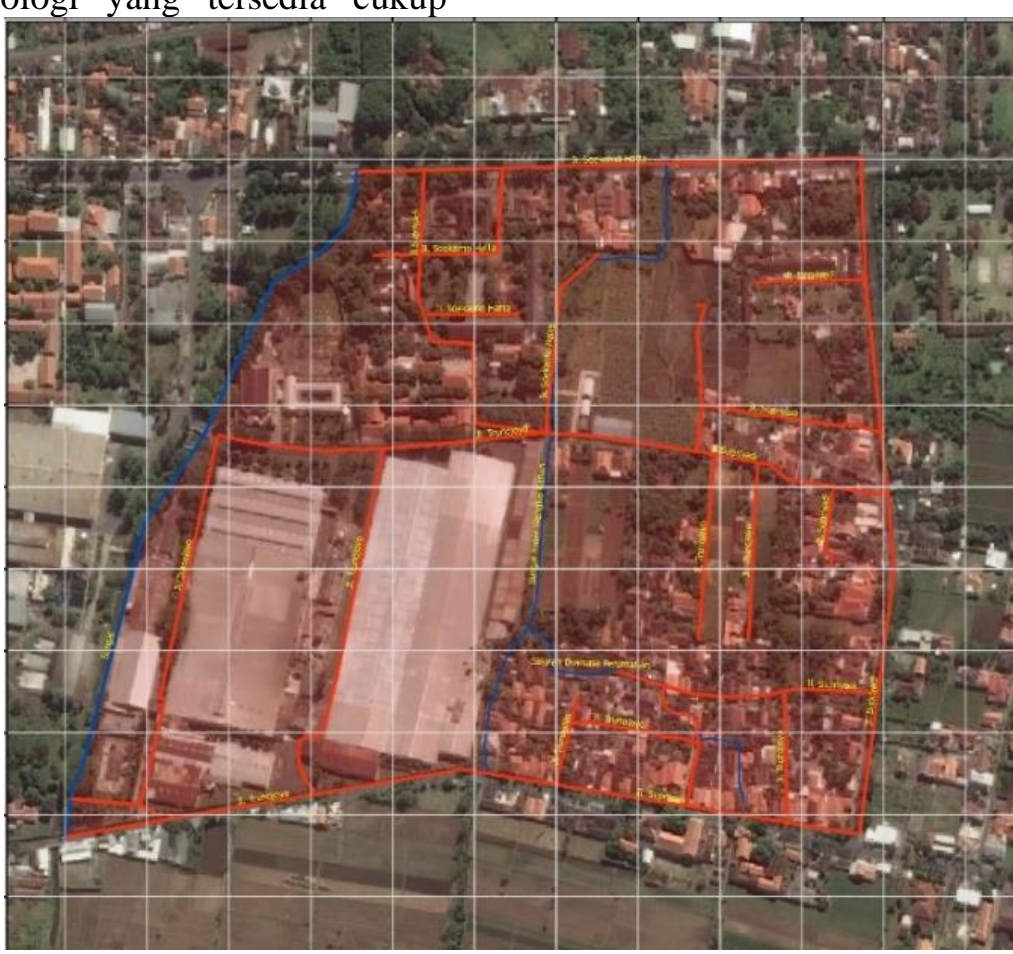

Gambar 1 DTA Lokasi Studi

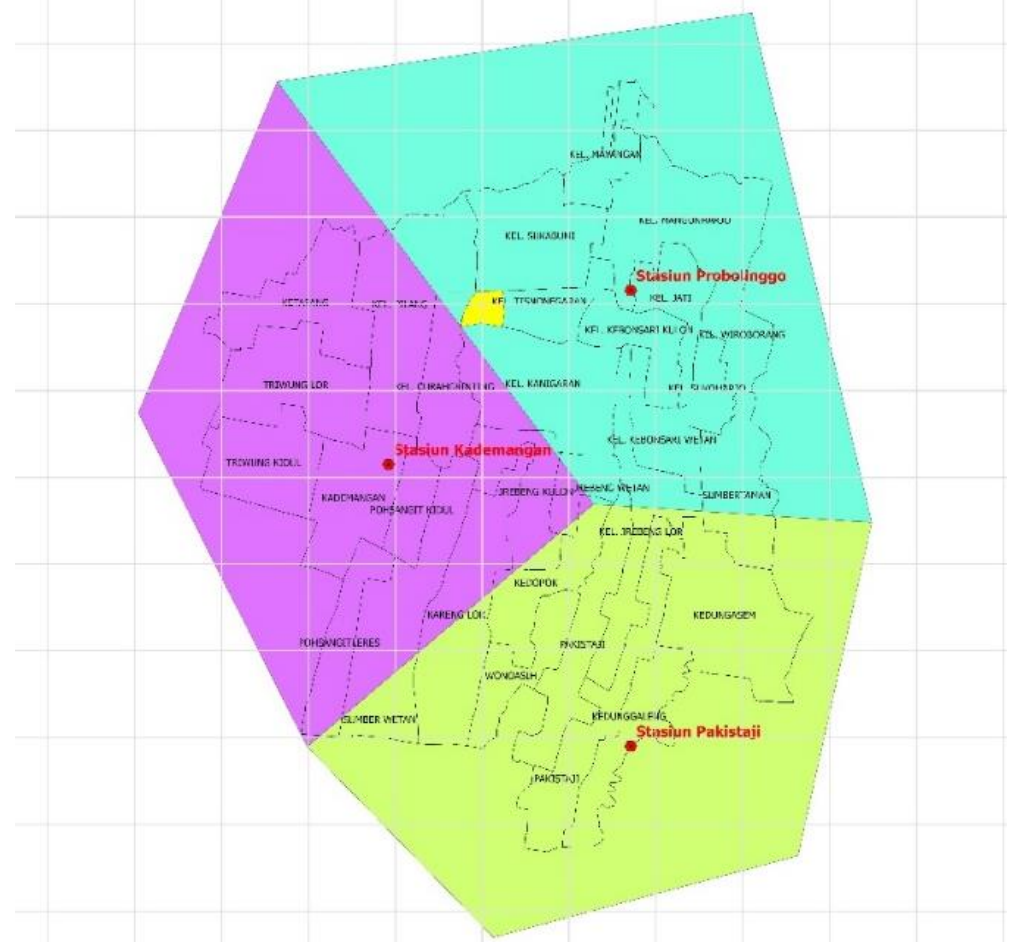

Gambar 2 Pembagian Luas Pengaruh Poligon Thiessen

\section{Curah Hujan Rerata Daerah}

Perhitungan curah hujan rerata daerah pada lokasi studi dipilih menggunakan metode poligon Thiessen karena penyebaran lokasi stasiun penakar hujan di Kota Probolinggo tidak merata, dan semua stasiun penakar hujan tersebut berada di luar DTA daerah studi, dapat dilihat pada Gambar 2. 
Dari hasil analisis curah hujan rerata daerah menggunakan metode Poligon Thiessen sebagaimana disajikan pada Gambar 2 didapatkan bahwa daerah studi (daerah berwarna kuning) dipengaruhi sepenuhnya (100\%) oleh Stasiun Probolinggo, sehingga untuk curah hujan rerata daerah studi adalah data curah hujan harian maksimum Stasiun Probolinggo, sebagaimana disajikan pada Tabel 2.

\section{Curah Hujan Rancangan}

Pada studi ini dilakukan dua analisis metode distribusi untuk mendapatkan curah hujan rancangan, yaitu metode distribusi
Gumbel dan metode distribusi Log Pearson tipe III, dengan pertimbangan bahwa 2 (dua) metode distribusi tersebut lebih dapat digunakan untuk semua jenis sebaran data.

Hasil analisis curah hujan rancangan menggunakan metode distribusi Gumbel dan metode distribusi Log Pearson tipe III disajikan pada Tabel 3. Kemudian dari dua metode distribusi yang dilakukan tersebut dipilih yang memenuhi persyaratan statistik sebagaimana disajikan pada Tabel 4 dan melalui uji ke-sesuaian distribusi frekuensi sebagaimana di-sajikan pada Tabel 5 dan Tabel 6.

Tabel 2 Curah Hujan Rerata Daerah Metode Poligon Thiessen

\begin{tabular}{c|c|c|c|c|c|c|c|c|c}
\hline Tahun & $\begin{array}{c}\text { CH } \\
\text { Rerata }\end{array}$ & Tahun & $\begin{array}{c}\text { CH } \\
\text { Rerata }\end{array}$ & Tahun & $\begin{array}{c}\text { CH } \\
\text { Rerata }\end{array}$ & Tahun & $\begin{array}{c}\text { CH } \\
\text { Rerata }\end{array}$ & Tahun & $\begin{array}{c}\text { CH } \\
\text { Rerata }\end{array}$ \\
\hline 1990 & 145 & 1996 & 98 & 2002 & 115 & 2008 & 70 & 2014 & 107 \\
\hline 1991 & 72 & 1997 & 55 & 2003 & 89 & 2009 & 216 & 2015 & 133 \\
\hline 1992 & 82 & 1998 & 90 & 2004 & 72 & 2010 & 121 & 2016 & 153 \\
\hline 1993 & 130 & 1999 & 94 & 2005 & 95 & 2011 & 98 & & \\
\hline 1994 & 140 & 2000 & 90 & 2006 & 98 & 2012 & 83 & & \\
\hline 1995 & 123 & 2001 & 103 & 2007 & 126 & 2013 & 124 & & \\
\hline
\end{tabular}

Tabel 3 Curah Hujan Rancangan Metode Distribusi Gumbel dan Metode Log Pearson tipe III

\begin{tabular}{c|c|c|c|c}
\hline No & $\begin{array}{c}\text { Kala Ulang } \\
\text { (tahun) }\end{array}$ & $\begin{array}{c}\text { Probabilitas } \\
(\%)\end{array}$ & $\begin{array}{c}\text { Curah Hujan Rancangan } \\
\text { Metode Gumbel } \\
(\mathrm{mm})\end{array}$ & $\begin{array}{c}\text { Curah Hujan Rancangan } \\
\text { Metode Log Pearson tipe III } \\
(\mathrm{mm})\end{array}$ \\
\hline 1 & 1.01 & 99.01 & 47.196 & 52.099 \\
\hline 2 & 2 & 50 & 100.258 & 102.625 \\
\hline 3 & 5 & 20 & 126.413 & 125.304 \\
\hline
\end{tabular}

Tabel 4 Rekapitulasi Syarat Pemilihan Distribusi

\begin{tabular}{c|c|c|c|c}
\hline No. & \multicolumn{1}{|c|}{$\begin{array}{c}\text { Metode Distribusi } \\
\text { Probabilitas }\end{array}$} & Kriteria & Hasil & $\begin{array}{c}\text { Keterangan } \\
\text { Hasil Uji }\end{array}$ \\
\hline 1 & Distribusi Gumbel & $\mathrm{Cs} \leq 1.1396$ & $\mathrm{Cs}=0.1329$ & Diterima \\
\hline & & $\mathrm{Ck} \leq 5.4002$ & $\mathrm{Ck}=-0.6859$ & Diterima \\
\hline 2 & Distribusi Log Pearson tipe III & $\mathrm{Cs} \neq 0$ & $\mathrm{Cs}=-0.3975$ & Diterima \\
\hline & & & $\mathrm{Ck}=-0.1740$ & Diterima \\
\hline
\end{tabular}

\section{Uji Kesesuaian Distribusi Frekuensi}

Tabel 5 Rekapitulasi Hasil Pengujian Kesesuaian Distribusi Frekuensi Chi-Square

\begin{tabular}{l|l|c|l|c}
\hline \multirow{2}{*}{ No } & Metode Distribusi & Uji Chi-Square $\left(\mathbf{X}^{2}\right.$ hitung $<\mathbf{X}^{2}$ kritis $)$ & \multirow{2}{*}{ Hasil Uji } \\
\cline { 3 - 5 } & & $\mathbf{X}^{2}$ hitung & \multicolumn{1}{|c}{$\mathbf{X}^{2}$ kritis } & \\
\hline 1 & Distribusi Gumbel & 6.308 & $6.25(\alpha=0.1)$ & Tidak diterima \\
\hline \multirow{2}{*}{2} & & & $7.82(\alpha=0.05)$ & Diterima \\
\hline & Distribusi Log Pearson tipe III & 5.846 & $6.25(\alpha=0.1)$ & Diterima \\
\hline
\end{tabular}


Tabel 6 Rekapitulasi Hasil Pengujian Kesesuaian Distribusi Frekuensi Smirnov-Kolmogorov

\begin{tabular}{l|l|c|c|c}
\hline \multirow{2}{*}{ No } & Metode Distribusi & \multicolumn{2}{|c|}{$\begin{array}{c}\text { Uji Smirnof Kolmogorof } \\
(\Delta \text { maks }<\Delta \text { kritis })\end{array}$} & \multirow{2}{*}{ Hasil Uji } \\
\cline { 3 - 4 } & & $\mathbf{X}^{2}$ hitung & \multicolumn{1}{|c}{$\mathbf{X}^{2}$ kritis } & \\
\hline 1 & Distribusi Gumbel & 0.22679 & $0.236(\alpha=0.1)$ & Diterima \\
\hline & & & $0.264(\alpha=0.05)$ & Diterima \\
\hline 2 & Distribusi Log Pearson tipe III & 0.08117 & $0.236(\alpha=0.1)$ & Diterima \\
\hline & & & $0.264(\alpha=0.05)$ & Diterima \\
\hline
\end{tabular}

Berdasarkan hasil rekapitulasi syarat pemilihan distribusi terhadap parameter statistik yang disajikan pada Tabel 4 dapat dilihat bahwa 2 (dua) metode distribusi yang dipilih telah memenuhi persyaratan.

Sedangkan berdasarkan hasil dari uji kesesuaian distribusi yang disajikan pada Tabel 5 dan Tabel 6 yaitu uji Chi-Kuadrat dan uji Smirnov-Kolmogorov, pada derajat kepercayaan $(\alpha)=5 \%$ baik metode distribusi Gumbel dan metode distribusi Log Pearson tipe III memenuhi persyaratan $\left(\mathrm{X}^{2}\right.$ hitung $<\mathrm{X}^{2}$ cr $; \Delta$ maks $<\Delta$ cr), namun demikian pada studi ini dipilih metode distribusi Log Pearson tipe III karena dalam analisis diperoleh nilai parameter hitung ( $\mathrm{X}^{2}$ hitung dan $\Delta$ maks) yang lebih kecil jika dibanding dengan metode distribusi Gumbel, hal ini mengidentifikasikan bahwa metode distribusi Log Pearson tipe III lebih aman. Sehingga untuk analisis selanjutnya dipilih hasil analisis curah hujan rancangan ber-dasarkan metode distribusi Log Pearson tipe III.

\section{Analisis Debit Rancangan}

Pada studi ini, perencanaan drainase di daerah studi menggunakan kala ulang 5 (lima) tahun, karena berdasarkan analisis terhadap kejadian genangan historis, intensitas hujan yang menyebabkan genangan di lokasi studi mendekati dengan nilai intensitas hujan kala ulang 2 (dua) tahun.

Input yang diolah dalam analisis debit rancangan adalah skema sistem drainase dan data teknis saluran drainase eksisting. Terdapat 25 (dua puluh lima) saluran drainase eksisting pada DTA daerah studi. Analisis penanganan dititikberatkan pada saluran yang diduga tidak mampu menampung debit rancangan.

Pada studi ini debit rancangan $\left(\mathrm{Q}_{\mathrm{R}}\right)$ merupakan jumlah debit air hujan kala ulang 5 (lima) tahun $\left(\mathrm{Q}_{\mathrm{AH}}\right)$ dan debit limbah domestik $\left(\mathrm{Q}_{\mathrm{AK}}\right)$. Hasil rekapitulasi perhitungan debit rancangan $\left(\mathrm{Q}_{\mathrm{R}}\right)$ disajikan pada Tabel 7.

Debit air hujan dihitung dengan rumus Rasional. Sedangkan debit limbah domestik adalah debit yang berasal dari buangan hasil aktivitas penduduk. Untuk memperkirakannya terlebih dahulu harus diketahui jumlah kebutuhan air rata-rata untuk daerah studi. Berdasarkan pengklasifikasian jenis kota, maka pada studi ini kebutuhan air diambil 150 liter / hari / orang.

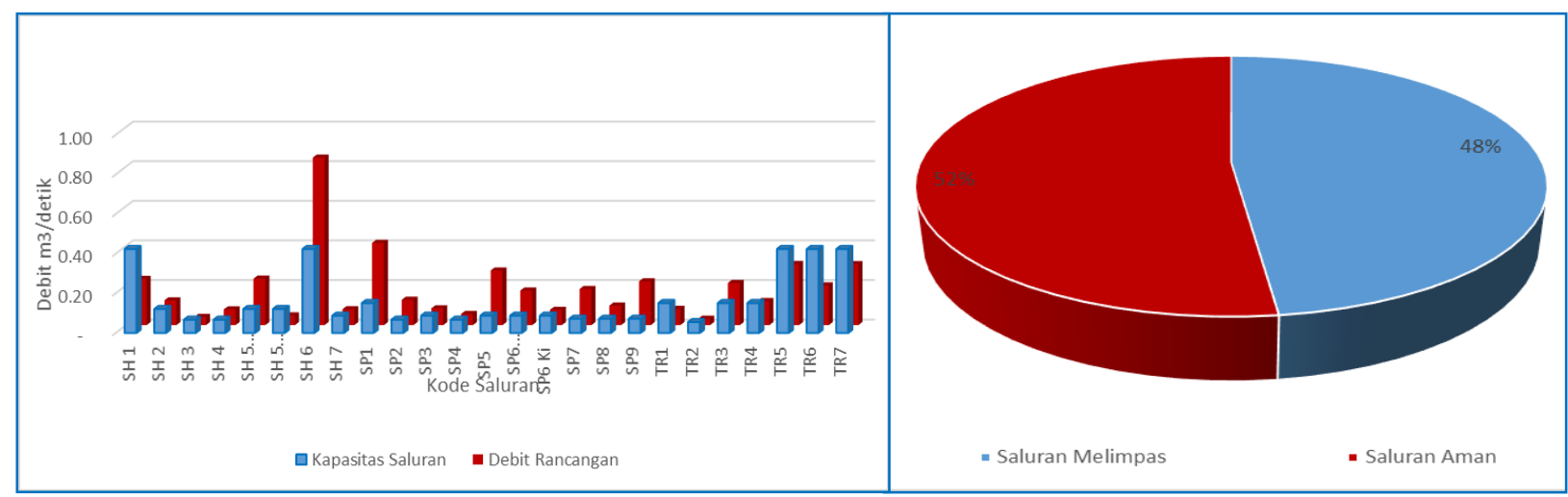

Gambar 3 Grafik Hasil Evaluasi Kapasitas Saluran Drainase Eksisting Terhadap Debit Rancangan Kala Ulang 5 Tahun 
Tabel 7 Evaluasi Kapasitas Saluran Drainase Eksisting Terhadap Debit Rancangan Kala Ulang 5 Tahun

\begin{tabular}{|c|c|c|c|c|c|c|}
\hline No & Nama Ruas Saluran & Kode & $\begin{array}{c}\mathbf{Q}_{\mathbf{s}} \\
\left(\mathrm{m}^{3} / \text { detik }\right)\end{array}$ & $\begin{array}{c}\mathbf{Q}_{\mathbf{R}} \\
\left(\mathrm{m}^{3} / \text { detik }\right)\end{array}$ & $\begin{array}{c}\text { Q Gen } \\
\left(\mathrm{m}^{3} / \text { detik }\right)\end{array}$ & Ket. \\
\hline 1 & Saluran Jl. Soekarno Hatta 1 & SH 1 & 0.4235 & 0.3060 & - & Aman \\
\hline 2 & Saluran J1. Soekarno Hatta 2 & SH 2 & 0.1209 & 0.1249 & 0.0040 & Melimpas \\
\hline 3 & Saluran J1. Soekarno Hatta 3 & SH 3 & 0.0667 & 0.0409 & - & Aman \\
\hline 4 & Saluran Jl. Soekarno Hatta 4 & $\mathrm{SH} 4$ & 0.0667 & 0.0792 & 0.0125 & Melimpas \\
\hline 5 & Saluran Jl. Soekarno Hatta $5 \mathrm{Ka}$ & $\mathrm{SH} 5 \mathrm{Ka}$ & 0.1508 & 0.2344 & 0.0837 & Melimpas \\
\hline 6 & Saluran Jl. Soekarno Hatta $5 \mathrm{Ki}$ & $\mathrm{SH} 5 \mathrm{Ki}$ & 0.1209 & 0.0489 & - & Aman \\
\hline 7 & Saluran Jl. Soekarno Hatta 6 & SH 6 & 0.4235 & 0.7868 & 0.3633 & Melimpas \\
\hline 8 & Saluran Jl. Soekarno Hatta 7 & SH 7 & 0.0873 & 0.0798 & - & Aman \\
\hline 9 & Saluran J1. Supriadi 1 & SP1 & 0.1508 & 0.2243 & 0.0735 & Melimpas \\
\hline 10 & Saluran J1. Supriadi 2 & SP2 & 0.0667 & 0.1277 & 0.0610 & Melimpas \\
\hline 11 & Saluran J1. Supriadi 3 & SP3 & 0.0873 & 0.0846 & - & Aman \\
\hline 12 & Saluran J1. Supriadi 4 & SP4 & 0.0667 & 0.0559 & - & Aman \\
\hline 13 & Saluran J1. Supriadi 5 & SP5 & 0.1209 & 0.2251 & 0.1041 & Melimpas \\
\hline 14 & Saluran Jl. Supriadi $6 \mathrm{Ka}$ & SP6 Ka & 0.1209 & 0.1581 & 0.0372 & Melimpas \\
\hline 15 & Saluran Jl. Supriadi $6 \mathrm{Ki}$ & SP6 Ki & 0.1209 & 0.0768 & - & Aman \\
\hline 16 & Saluran Jl. Supriadi 7 & SP7 & 0.0873 & 0.1416 & 0.0543 & Melimpas \\
\hline 17 & Saluran J1. Supriadi 8 & SP8 & 0.0873 & 0.0985 & 0.0112 & Melimpas \\
\hline 18 & Saluran J1. Supriadi 9 & SP9 & 0.0873 & 0.1328 & 0.0455 & Melimpas \\
\hline 19 & Saluran Jl. Trunojoyo 1 & TR1 & 0.1508 & 0.0818 & - & Aman \\
\hline 20 & Saluran Jl. Trunojoyo 2 & TR2 & 0.0549 & 0.0321 & - & Aman \\
\hline 21 & Saluran Jl. Trunojoyo 3 & TR3 & 0.1508 & 0.2127 & 0.0619 & Melimpas \\
\hline 22 & Saluran Jl. Trunojoyo 4 & TR4 & 0.1508 & 0.1216 & - & Aman \\
\hline 23 & Saluran Jl. Trunojoyo 5 & TR5 & 0.4235 & 0.1388 & - & Aman \\
\hline 24 & Saluran Jl. Trunojoyo 6 & TR6 & 0.4235 & 0.2000 & - & Aman \\
\hline 25 & Saluran J1. Trunojoyo 7 & TR7 & 0.4235 & 0.3908 & - & Aman \\
\hline \multicolumn{5}{|c|}{ JUMLAH } & 0.9122 & \\
\hline
\end{tabular}

\section{Analisis Evaluasi Kapasitas Saluran Drainase}

Evaluasi kapasitas saluran dilakukan dengan melakukan perbandingan antara debit rancangan $\left(\mathrm{Q}_{\mathrm{R}}\right)$ dengan kapasitas saluran drainase eksistingnya $\left(\mathrm{Q}_{\mathrm{S}}\right)$. Hasil evaluasi didapatkan dengan menarik kesimpulan dari asumsi bahwa:

$\mathrm{Q}_{\mathrm{S}}>\mathrm{Q}_{\mathrm{R}}: \begin{aligned} & \text { saluran aman, tidak terjadi } \\ & \text { limpasan }\end{aligned}$

$\mathrm{Q}_{\mathrm{S}}<\mathrm{Q}_{\mathrm{R}}$ : saluran tidak dapat menampung limpasan

Dari hasil evaluasi kapasitas saluran pada Tabel 7 menunjukkan bahwa 12 (dua belas) saluran (48\%) tidak dapat menampung debit rancangan kala ulang 5 (lima) tahun, sehingga pada 12 (dua belas) saluran inilah analisis penanganan dititikberatkan.

\section{Analisis Penanganan Genangan}

Kendala keterbatasan lahan untuk dilakukan pelebaran terhadap dimensi saluran drainase eksisting, maka rencana penanganan yang diusulkan dalam studi "Kajian Penanggulangan Genangan Yang Terintegrasi Di Kawasan Pilang, Probolinggo" adalah dengan sistem baru yang terintegrasi dengan saluran drainase eksisting, diharapkan integrasi antara dua sistem tersebut dapat bekerja optimal dalam mengendalikan limpasan.

\section{Koefisien Permeabilitas Lapangan}

Untuk mengetahui karakteristik daerah studi, maka dilakukan serangkaian pengujian tanah di Laboratorium Mekanika Tanah Teknik Sipil Universitas Brawijaya pada sampel tanah di daerah studi. Pengambilan sampel tanah di lokasi studi dilakukan pada 3 (tiga) titik dan pada kedalaman $1.5 \mathrm{~m}$.

Berdasarkan hasil analisis gradasi butiran tanah, tanah pada lokasi studi diklasifikan pada 
jenis tanah lempung sedikit berpasir, dan hasil uji falling head nilai koefisien permeabilitas tanah $(\mathrm{K})$ pada lokasi studi sebesar $4.49 \times 10^{-6}$ $\mathrm{cm} /$ detik. Pada dasarnya jika dilihat pada Tabel 1 , jenis tanah di daerah studi termasuk tanah lempung berlanau dengan kemampuan meresap yang sangat lemah (very low permeability).

\section{Analisis Sumur Tampungan dan Kolam Detensi}

Oleh karena karakteristik tanah di daerah studi kurang mendukung untuk penanganan sistem peresapan, maka analisis penanganan genangan yang diusulkan yaitu berupa sumur tampungan dan kolam detensi.

Sistem kerja sumur tampungan pada studi ini sebagaimana ditunjukkan pada Gambar 4, yaitu mengendalikan limpasan air hujan dari atap untuk dimasukkan pada sumur tampungan melalui talang, setelah sumur tampungan penuh, limpasan air hujan baru dialirkan ke saluran drainase eksisting, sehingga terdapat waktu tambahan tibanya limpasan pada saluran drainase eksisting.

Untuk sistem kerja kolam detensi adalah dengan membantu saluran drainase eksisting dalam menerima beban debit rancangan. Terdapat pipa inlet untuk mengalirkan kelebihan beban dari saluran drainase eksisting menuju kolam detensi, kelebihan tersebut ditampung sementara pada kolam detensi, ketika saluran drainase eksisting telah berkurang bebannya, maka air pada kolam detensi dipompa keluar. Terdapat waktu penundaan tibanya air limpasan hujan pada saluran drainase eksisting akibat upaya penanganan yang diusulkan tersebut. Integrasi antara dua sistem tersebut diharapkan dapat bekerja optimal dalam menanggulangi genangan yang terjadi. Skema kolam detensi disajikan pada Gambar 5.

Sumur tampungan untuk mereduksi genangan di daerah studi pada 11 (sebelas) saluran direncanakan dengan dimensi diameter sumur $1 \mathrm{~m}$ dan kedalaman air di sumur $2 \mathrm{~m}$, sedangkan untuk ruas saluran Jl. Soekarno Hatta 6 (SH6), direncanakan dengan dimensi diameter sumur $1.5 \mathrm{~m}$ dan kedalaman $2 \mathrm{~m}$.

Penentuan jumlah kebutuhan sumur tampungan pada tiap area saluran yang bermasalah didasarkan pada debit genangan (Qgen) yang terjadi, dimana Qgen merupakan kelebihan debit yang tidak tertampung di saluran drainase eksisting, yaitu selisih antara dedit rancangan $\left(\mathrm{Q}_{\mathrm{R}}\right)$ dengan kapasitas saluran ( $\mathrm{Q}_{\mathrm{S}}$.

Pada lokasi Jl. Soekarno Hatta 2 (SH2), debit tampungan untuk satu buah sumur tampungan adalah sebesar $0.0029 \mathrm{~m}^{3} /$ detik, sehingga untuk lokasi SH2 dibutuhkan 2 (dua) sumur tampungan. Rekapitulasi jumlah kebutuhan sumur tampungan pada lokasi studi disajikan pada Tabel 8.

Tabel 8 Rekapitulasi Kebutuhan Sumur Tampungan

\begin{tabular}{|c|l|c|c|c|c|c|}
\hline No & Kode & $\begin{array}{c}\mathbf{Q}_{\mathbf{S}} \\
\left(\mathrm{m}^{3} / \text { detik }\right)\end{array}$ & $\begin{array}{c}\mathbf{Q}_{\mathbf{R}} \\
\left(\mathrm{m}^{3} / \text { detik }\right)\end{array}$ & $\begin{array}{c}\text { Qgen } \\
\left(\mathrm{m}^{3} / \text { detik }\right)\end{array}$ & $\begin{array}{c}\text { Qtamp } \\
\left(\mathrm{m}^{3} / \text { detik }\right)\end{array}$ & $\mathbf{n}$ \\
\hline 1 & SH2 & 0.121 & 0.125 & 0.004 & 0.0029 & 2 \\
\hline 2 & SH4 & 0.067 & 0.079 & 0.013 & 0.0029 & 5 \\
\hline 3 & SH5Ka & 0.151 & 0.234 & 0.084 & 0.0020 & 42 \\
\hline 4 & SH6 & 0.423 & 0.787 & 0.218 & 0.0061 & 36 \\
\hline 5 & SP1 & 0.151 & 0.224 & 0.074 & 0.0013 & 58 \\
\hline 6 & SP2 & 0.067 & 0.128 & 0.061 & 0.0025 & 24 \\
\hline 7 & SP5 & 0.121 & 0.171 & 0.050 & 0.0025 & 21 \\
\hline 8 & SP6Ka & 0.121 & 0.158 & 0.037 & 0.0026 & 15 \\
\hline 9 & SP7 & 0.087 & 0.142 & 0.054 & 0.0025 & 22 \\
\hline 10 & SP8 & 0.087 & 0.099 & 0.011 & 0.0024 & 5 \\
\hline 11 & SP9 & 0.087 & 0.119 & 0.032 & 0.0033 & 10 \\
\hline 12 & TR3 & 0.151 & 0.213 & 0.062 & 0.0018 & 36 \\
\hline JUMLAH KEBUTUHAN SUMUR TAMPUNGAN & $\mathbf{2 7 6}$ \\
\hline
\end{tabular}




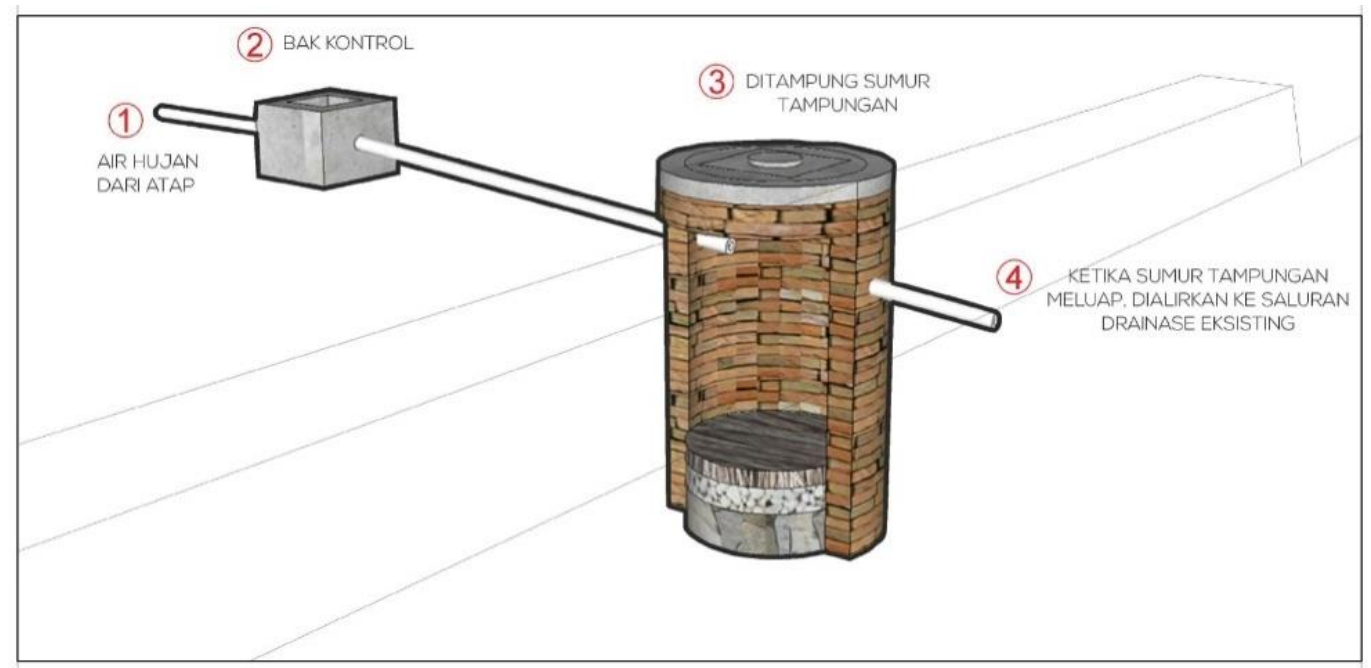

Gambar 4 Sketsa Sumur Tampungan

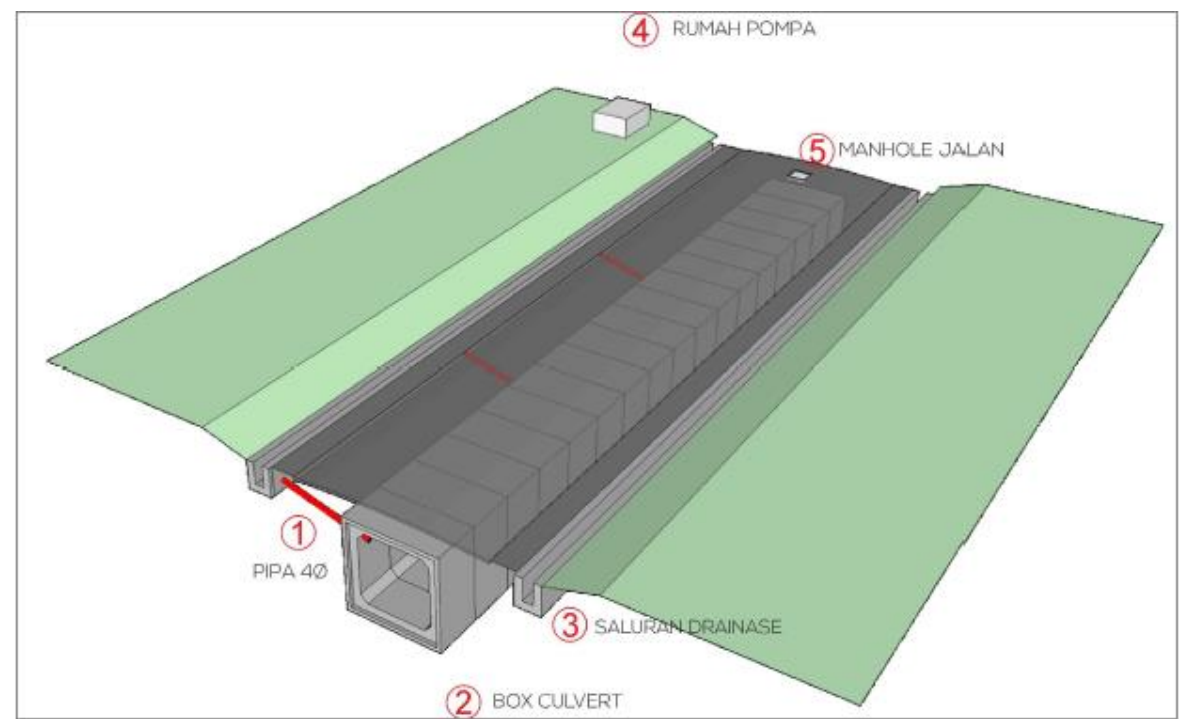

Gambar 5 Sketsa Kolam Detensi

Waktu pengisian satu sumur tampungan dihitung dengan cara:

$$
\begin{aligned}
\mathrm{T} & =\frac{\text { volumesumur }}{\text { Qtampungsumur }} \\
& =\frac{0.25 \pi \times(1 \mathrm{~m})^{2} \times 2 \mathrm{~m}}{0.0029 \mathrm{~m}^{3} / \text { det ik }} \\
& =588.4 \mathrm{detik}=0.163 \mathrm{jam}
\end{aligned}
$$

sehingga untuk saluran $\mathrm{SH} 2$ waktu pengisian diperoleh selama 0.163 jam.

Karena tidak tersedia cukup lahan untuk membuat sumur tampungan sebanyak 42 buah pada area di sekitar saluran SH5Ka, sehingga pada lokasi tersebut upaya penanggulan yang diusulkan berupa kolam detensi di bawah permukaan jalan.
Kolam detensi direncanakan menerima beban genangan yang tidak bisa ditampung oleh saluran drainase eksisting (Qgen) SH5Ka sebesar $0.0837 \mathrm{~m}^{3} /$ detik. Perhitungan beban yang diterima kolam detensi adalah dengan membuat grafik hidrograf untuk aliran masuk. Perhitungan aliran inflow untuk kolam detensi disajikan pada Tabel 9.

Dari hasil perhitungan pada Tabel 9 diperoleh volume aliran masuk pada kolam detensi sebesar $383.328 \mathrm{~m}^{3}$, sehingga kolam detensi direncanakan dengan dimensi lebar 1.5 $\mathrm{m}$, kedalaman $1.5 \mathrm{~m}$, dan panjang $170 \mathrm{~m}$. Untuk mengosongkan kolam tersebut digunakan pompa dengan kapasitas $10 \mathrm{~m}^{3} /$ menit. Dari hasil analisis, waktu pengisian kolam detensi adalah selama 76.40 menit, sedangkan waktu pe-ngosongan kolam selama 38.355 menit. 
Tabel 9 Perhitungan Hidrograf Aliran Inflow untuk Kolam Detensi

\begin{tabular}{c|c|c|c|c|c|c|}
\hline No & Waktu & $\begin{array}{c}\text { Selisih } \\
\text { Waktu } \\
\text { detik }\end{array}$ & $\begin{array}{c}\text { Laju Debit } \\
\text { Inflow } \\
\mathrm{m}^{3} / \mathrm{detik}\end{array}$ & $\begin{array}{c}\text { Rata-rata Debit } \\
\text { Inflow } \\
\mathrm{m}^{3} / \mathrm{detik}\end{array}$ & $\begin{array}{c}\text { Tambahan } \\
\text { Volume Inflow } \\
\mathrm{m}^{3}\end{array}$ & $\begin{array}{c}\text { Jumlah Vol. } \\
\text { Kumulatif Inflow } \\
\mathrm{m}^{3}\end{array}$ \\
\hline 1 & 0.00 & 0.0 & 0.000 & 0.000 & 0.000 & 0.000 \\
\hline 2 & 10.00 & 1200.0 & 0.029 & 0.015 & 17.438 & 17.438 \\
\hline 3 & 20.00 & 1200.0 & 0.058 & 0.044 & 52.313 & 69.750 \\
\hline 4 & 29.80 & 1176.0 & 0.084 & 0.071 & 83.393 & 153.143 \\
\hline 5 & 40.00 & 1224.0 & 0.064 & 0.074 & 90.396 & 243.539 \\
\hline 6 & 44.76 & 571.2 & 0.056 & 0.060 & 34.170 & 277.709 \\
\hline 7 & 50.00 & 628.8 & 0.046 & 0.051 & 32.087 & 309.796 \\
\hline 8 & 60.00 & 1200.0 & 0.029 & 0.038 & 45.156 & 354.952 \\
\hline 9 & 70.00 & 1200.0 & 0.011 & 0.020 & 24.055 & 379.006 \\
\hline 10 & 76.40 & 768.0 & 0.000 & 0.006 & 4.321 & 383.328 \\
\hline 11 & 80.00 & 432.0 & 0.000 & 0.000 & 0.000 & 383.328 \\
\hline \hline
\end{tabular}

Tabel 10 Reduksi Genangan Setelah Adanya Penanganan Secara Terintegrasi

\begin{tabular}{|c|c|c|c|c|c|c|c|c|c|}
\hline \multirow[t]{2}{*}{ No } & \multirow{2}{*}{$\begin{array}{c}\text { Kode } \\
\text { Saluran }\end{array}$} & \multirow{2}{*}{$\begin{array}{c}\mathbf{Q}_{\mathbf{s}} \\
\left(\mathrm{m}^{3} / \text { detik }\right)\end{array}$} & \multirow{2}{*}{$\begin{array}{c}\mathbf{Q}_{\mathbf{R}} \\
\left(\mathrm{m}^{3} / \text { detik }\right)\end{array}$} & \multirow{2}{*}{$\begin{array}{c}\text { Qgen } \\
\left(\mathrm{m}^{3} / \text { detik }\right)\end{array}$} & \multicolumn{3}{|c|}{ Penanganan yang Terintegrasi } & \multirow{2}{*}{$\begin{array}{c}\text { Jumlah Debit } \\
\text { Penanganan } \\
\left(\mathrm{m}^{3} / \text { detik }\right)\end{array}$} & \multirow{2}{*}{$\begin{array}{c}\text { Re- } \\
\text { duksi Ge } \\
\text { nangan }\end{array}$} \\
\hline & & & & & $\begin{array}{c}\text { Saluran } \\
\text { Eksisting } \\
\left(\mathrm{m}^{3} / \text { detik) }\right.\end{array}$ & $\begin{array}{c}\text { Kolam } \\
\text { Detensi } \\
\left(\mathrm{m}^{3} / \text { detik }\right)\end{array}$ & $\begin{array}{c}\text { Sumur } \\
\text { Tampungan } \\
\left(\mathrm{m}^{3} / \text { detik }\right)\end{array}$ & & \\
\hline 1 & SH 2 & 0.1209 & 0.1249 & 0.0040 & 0.1209 & - & 0.0087 & 0.1296 & $100 \%$ \\
\hline 2 & SH 4 & 0.0667 & 0.0792 & 0.0125 & 0.0667 & - & 0.0139 & 0.0806 & $100 \%$ \\
\hline 3 & SH $5 \mathrm{Ka}$ & 0.1508 & 0.2344 & 0.0837 & 0.1508 & 0.0837 & - & 0.2344 & $100 \%$ \\
\hline 4 & SH 6 & 0.4235 & 0.7868 & 0.3633 & 0.4235 & - & 0.3555 & 0.7790 & $100 \%$ \\
\hline 5 & SP1 & 0.1508 & 0.2243 & 0.0735 & 0.1508 & - & 0.0735 & 0.2243 & $100 \%$ \\
\hline 6 & SP2 & 0.0667 & 0.1277 & 0.0610 & 0.0667 & - & 0.0939 & 0.1606 & $100 \%$ \\
\hline 7 & SP5 & 0.1209 & 0.2251 & 0.1041 & 0.1209 & - & 0.2764 & 0.3973 & $100 \%$ \\
\hline 8 & SP6 Ka & 0.1209 & 0.1581 & 0.0372 & 0.1209 & - & 0.0979 & 0.2188 & $100 \%$ \\
\hline 9 & SP7 & 0.0873 & 0.1416 & 0.0543 & 0.0873 & - & 0.1813 & 0.2686 & $100 \%$ \\
\hline 10 & SP8 & 0.0873 & 0.0985 & 0.0112 & 0.0873 & - & 0.0377 & 0.1250 & $100 \%$ \\
\hline 11 & SP9 & 0.0873 & 0.1328 & 0.0455 & 0.0873 & - & 0.0607 & 0.1480 & $100 \%$ \\
\hline 12 & TR3 & 0.1508 & 0.2127 & 0.0619 & 0.1508 & - & 0.0687 & 0.2194 & $100 \%$ \\
\hline
\end{tabular}

Analisis Potensi Sistem Penanggulangan Terintegrasi yang Diusulkan

Sebagaimana telah disebutkan di atas, bahwa analisis penanganan genangan dititikberatkan pada 12 (dua belas) saluran yang tidak mampu menampung beban debit rancangan kala ulang 5 (lima) tahun. Potensi reduksi banjir setelah dilakukan penanganan secara ter-integrasi dapat dilihat pada Tabel 10.

Pada Tabel 10 menunjukkan jumlah debit penanganan pada 12 (dua belas) saluran lebih besar dari debit rancangannya $\left(\mathrm{Q}_{\mathrm{R}}\right)$, hal ini mengidentifikasikan bahwa antara sistem baru yang diusulkan dan sistem drainase eksisting terintegrasi dalam menerima debit rancangan kala ulang 5 (lima) tahun, sehingga dapat disimpulkan bahwa potensi sistem drainase yang diusulkan dapat mereduksi genangan mencapai $100 \%$.
Sedangkan analisis terhadap potensi sistem yang diusulkan dalam menambah waktu tiba banjir dapat dilihat pada Tabel 11, bahwa pada saluran SH2, SH4, SH5Ka, SP1, dan SP8 sistem dapat menunda waktu tiba banjirnya hingga $100 \%$, sehingga saat menerima beban debit rancangan kala ulang 5 (lima) tahun, saluran drainase eksisting dapat menyalurkan beban limpasan sesuai kapasitas salurannya terlebih dahulu, karena sisa beban dari debit rancangan masih tertahan pada alternatif penanganan yang diusulkan.

Untuk saluran lain potensi mereduksi waktu tiba banjirnya belum mencapai $100 \%$, jika dirata-rata dari 12 (dua belas) saluran tersebut di atas potensi sistem yang diusulkan dalam menambah waktu tiba banjirnya adalah sebesar $83 \%$. 
Tabel 11 Analisis Waktu Tiba Banjir

\begin{tabular}{|c|c|c|c|c|c|c|c|c|c|c|}
\hline \multirow[t]{2}{*}{ No } & \multirow[t]{2}{*}{ Kode } & \multirow{2}{*}{$\begin{array}{c}\mathbf{Q}_{\mathbf{R}} \\
\left(\mathrm{m}^{3} / \text { detik }\right) \\
\end{array}$} & \multirow{2}{*}{$\begin{array}{c}\mathbf{Q s}_{\mathbf{s}} \\
\left(\mathrm{m}^{3} / \mathrm{detik}\right)\end{array}$} & \multicolumn{2}{|c|}{ Waktu Konsentrasi } & \multirow{2}{*}{$\begin{array}{c}\begin{array}{c}\text { kebutu- } \\
\text { han tc } \\
\text { (jam) }\end{array} \\
\end{array}$} & \multicolumn{3}{|c|}{ Waktu Delay } & \multirow{2}{*}{$\begin{array}{l}\text { Pros entase } \Sigma t \\
\text { terhadap } \\
\text { kebutuhan tc }\end{array}$} \\
\hline & & & & $\begin{array}{c}\mathbf{t} \\
(\mathrm{jam}) \\
\end{array}$ & $\begin{array}{c}\text { tc } \\
\text { (jam) } \\
\end{array}$ & & $\begin{array}{c}\mathbf{t 1} \\
\text { (jam) } \\
\end{array}$ & $\begin{array}{c}\mathbf{t 2} \\
(\mathrm{jam}) \\
\end{array}$ & $\begin{array}{c}\mathbf{\Sigma t} \\
\text { (jam) } \\
\end{array}$ & \\
\hline 1 & 2 & 3 & 4 & 5 & 6 & 7 & 8 & 9 & 10 & 12 \\
\hline 1 & SH 2 & 0.1249 & 0.1209 & 0.289 & 0.275 & 0.013 & 0.163 & 0.0025 & 0.166 & $100 \%$ \\
\hline 2 & SH 4 & 0.0792 & 0.0667 & 0.355 & 0.275 & 0.080 & 0.163 & 0.0025 & 0.166 & $100 \%$ \\
\hline 3 & SH $5 \mathrm{Ka}$ & 0.2344 & 0.1508 & 0.940 & 0.485 & 0.455 & 1.273 & 0.0000 & 1.273 & $100 \%$ \\
\hline 4 & SH 6 & 0.7868 & 0.4235 & 0.864 & 0.370 & 0.494 & 0.344 & 0.0025 & 0.346 & $70 \%$ \\
\hline 5 & SP1 & 0.2243 & 0.1508 & 1.158 & 0.970 & 0.188 & 0.217 & 0.0025 & 0.220 & $100 \%$ \\
\hline 6 & SP2 & 0.1277 & 0.0667 & 0.712 & 0.331 & 0.381 & 0.181 & 0.0025 & 0.184 & $48 \%$ \\
\hline 7 & SP5 & 0.2251 & 0.1209 & 0.616 & 0.349 & 0.268 & 0.187 & 0.0025 & 0.189 & $71 \%$ \\
\hline 8 & SP6 Ka & 0.1581 & 0.1209 & 0.540 & 0.312 & 0.228 & 0.175 & 0.0025 & 0.178 & $78 \%$ \\
\hline 9 & SP7 & 0.1416 & 0.0873 & 0.581 & 0.344 & 0.237 & 0.185 & 0.0025 & 0.188 & $79 \%$ \\
\hline 10 & SP8 & 0.0985 & 0.0873 & 0.428 & 0.358 & 0.071 & 0.190 & 0.0025 & 0.192 & $100 \%$ \\
\hline 11 & SP9 & 0.1328 & 0.0873 & 0.389 & 0.213 & 0.176 & 0.142 & 0.0025 & 0.145 & $82 \%$ \\
\hline 12 & TR3 & 0.2127 & 0.1508 & 0.992 & 0.593 & 0.399 & 0.256 & 0.0025 & 0.259 & $65 \%$ \\
\hline & & & & & & & & & & \\
\hline
\end{tabular}

Keterangan: $\mathrm{t} 1$ adalah waktu pengisian sumur tampungan / kolam detensi, t2 adalah waktu dari sumur tampungan menuju saluran drainase, $\Sigma \mathrm{t}$ adalah jumlah $\mathrm{t} 1 \mathrm{dan} \mathrm{t} 2$.

\section{PENUTUP}

\section{Kesimpulan}

Hasil evaluasi kapasitas saluran drainase eksisting terhadap debit rancangan kala ulang 5 (lima) tahun terdapat 12 (dua belas) saluran yang tidak dapat menampung debit rancangan pada DTA di lokasi studi. Saluran yang tidak dapat menampung debit rancangan mengidentifikasikan terjadinya genangan, sehingga arahan pengendalian air limpasan permukaan dilakukan pada catchment area saluran yang tidak memenuhi tersebut.

Berdasarkan hasil serangkaian pengujian tanah di Laboratorium Mekanika Tanah Teknik Sipil Universitas Brawijaya Malang bahwa nilai koefisien permeabilitas tanah pada lokasi studi sebesar $4.49 \times 10^{-6} \mathrm{~cm} /$ detik dan termasuk jenis tanah dengan kemampuan meresap yang sangat lemah (very low permeability). Oleh karena karakteristik tanah di daerah studi kurang mendukung, maka analisis penanganan ge-nangan yang diusulkan yaitu berupa sumur tampungan dan kolam detensi yang terintegrasi dengan saluran drainase eksisting sebagai pengendali limpasan yang terjadi. Prinsip kerja sumur tampungan dan kolam detensi adalah sebagai media penampung sementara limpasan air hujan agar air memiliki waktu tiba lebih lama di saluran drainase utama sehingga dapat menunda terjadinya luapan di saluran drainase eksisting.
Potensi sistem penanggulangan genangan secara terintegrasi yang diusulkan memiliki tingkat keberhasilan $100 \%$ dalam mereduksi genangan, sehingga dengan penerapan sistem tersebut diharapkan genangan dapat segera teratasi. Sedangkan potensi terhadap waktu tunda tiba banjir jika dirata-rata dari 12 (dua belas) saluran adalah sebesar $83 \%$, hal tersebut mengidentifikasikan integrasi antara dua sistem drainase, yaitu bahwa tambahan waktu tiba banjir tersebut dapat membantu saluran drainase eksisting dalam mengalirkan debit rancangan kala ulang 5 (lima) tahun.

\section{Saran}

Saran yang bisa diberikan untuk peneliti berikutnya adalah sebagai berikut:

- Perlu dilakukan pengukuran lebih detail terhadap panjang lereng dan kemiringan lereng (slope) pada lahan dan saluran, sehingga bisa diperoleh waktu tiba banjir yang lebih akurat.

- Mempertimbangkan penerapan ekodrainase pada wilayah non genangan, sehingga dapat dianalisis dampak penerapan tersebut terhadap penanggulangan genangan pada daerah tergenang.

- Dapat menggunakan alternatif penerapan ekodrainase yang lainnya untuk penanggulangan genangan seperti parit infiltrasi, 
biopori, kolam retensi apabila ketersediaan lahan pada lokasi studi memadai.

- Sebagai pembanding hasil analisis, pada penelitian selanjutnya dapat menggunakan bantuan aplikasi di bidang drainase, seperti SWMM, Bentle Sewergems, dll.

\section{DAFTAR PUSTAKA}

Arafat. Y. 2008. Reduksi Beban Aliran Drainase Permukaan Menggunakan Sumur Resapan. Jurnal SMARTek. 6 (3): 144-153.

Bisri, M., Titah, A. N. P. 2009. Imbuhan Air Tanah Buatan Untuk Mereduksi Genangan (Studi Kasus Di Kecamatan Batu Kota Batu). Jurnal Rekayasa Sipil Universitas Brawijaya. 3 (1):7790.

Guntoro, D.E, Donny, H., Evi, N. C. 2017. Pengelolaan Drainase Secara Terpadu Untuk Pengendalian Genangan Di Kawasan Sidokare Kabupaten Sidoarjo. Jurnal Teknik Pengairan Universitas Brawijaya. 8 (1):60-71.

Irawan, H. Soewignjo, A. N., Syawal, S. Korelasi Permeabilitas Berdasarkan
Ukuran Butiran dan Plastisitas Tanah. Jurnal Teknik Sipil Universitas Riau.

Rahmani, R. N., Sobriyah, Agus. H. W. 2016. Transformasi Hujan Harian ke Hujan Jam-jaman Menggunakan Metode Mononobe dan Pengalihragaman Hujan Aliran (Studi Kasus di DAS Tirtomoyo). e-Jurnal Matriks Teknik Sipil Universitas Sebelas Maret. 176185.

Soemarto, C. D. 1999. Hidrologi Teknik (Edisi $\mathrm{Ke}-2)$. Jakarta: Erlangga.

Solikin, Ery, S., Riyanto, H. 2017. Penanganan Genangan Dengan Sistem Polder Pada Wilayah Kota Banjarmasin. Jurnal Teknik Pengairan Universitas Brawijaya. 8 (1):15-25.

Sosrodarsono, S. 1978. Hidrologi Untuk Pengairan. Jakarta: PT. Pradnya Paramita.

Suripin. 2004. Sistem Drainase Perkotaan yang Berkelanjutan. Yogyakarta: Andi.

Yusuf, M. A. M., Damar, S., Heny, P. 2013. Pengendalian Banjir Genangan Dengan Sistem Sumur Resapan. Jurnal Teknik Sipil Unpak. 1-14. 